\author{
第69回日本内科学会满演会（1972年） \\ シンポジゥム 自己免疫性疾患 \\ 発言 自己免疫性朋疾舮の発生機転と自己抗体の病因的意義 \\ 能本大学医学部籍三队科教授 \\ 長䶊 秀夫

\section{SYMPOSIUM ON AUTOIMMUNE DISEASE. STUDIES ON MECHANISM OF LIVER CELL DAMAGE AND SIGNIFICANCES OF AUTOANTIBODIES IN AUTOIMMUNE LIVER DISEASES}

\title{
Hideo Nagashima
}

Professor of the Third Department of Internal Medicine, Kumamoto University Medical School

所細胞障害の免疫機模を明らかにするために は, humoral immunity $と$ cell mediated immunity からの検討が必要で方るが，それには缄器特異抗 原执よび抗体の㛟索が重要である，活動性慢性肺 炎や肝硬变のよらな慢性朋疾患ではしばしば流血 中に各種の肝細胞成分に対応する抗体が比較的 持続して出現するよらになる。 in vitroの実験か らはこれらの循環抗体のらち肝細胞膜ないLcell surface antigensに対する抗体（以下膜抗体と略 す）が肝細胞障害を起こす可能性があることを示 惨した. 肝細胞膜の分離, 精製はラット肝細胞よ り Takeuchi, H. \& Terayama, H. らの方法(Exptl. Cell Research, 40:32, 1965), 肝細胞成分 (mitochondria, nuclei, homogenate上清) の分離はHogeboom, G.H. らの力法に準じた。これらの各抗 原にFreund's complete adjuvantを加光，型の加 くウサギを货疫してそれでれの抗血清をえた。こ 孔らの扰保清は们れもplate gel chromatography

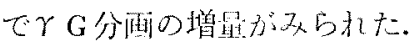

膜抗体の枱仙には，先の゙ラット旰をRinaldini氏

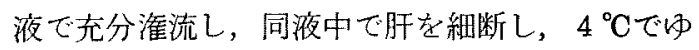
つくり 4 〜 時間擋捧し， 200 ッシュのステン レス製ネットで濾過し, $500 \mathrm{rpm}, 10$ 分，低温下 で遠沈し，遊離細胞を集め，TC- 199で細胞数を
$2 \times 10^{5} / \mathrm{ml}$ に調製する.これをsingle cover slip

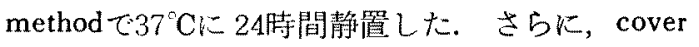
slipこ附着した肝細胞を $0.5 \%$ のlactoalbumin hydrolysate加生食水で 3 回洗浮後, 抗血清をcover slipが充分覆かれるだけ加光，室温 2 時間放置 後, 上述の生食水で 2 回洗浄, 過剩の抗体を除去 寸る. 次いで，タン二ン酸処理血球に蛋白量 10 $\mathrm{mg} / \mathrm{ml}$ に希釈した肝抗原 [homogenate 上清成分 （35,000 G，4時間遠沈)了を赤血球に被覆したも のをCover slipが覆われるだけ加兄，室温 2 時間 放置後, 前と同様に2 回洗浄後, 鏡検すると, 䀒 細胞に赤血球がロゼット状に粘着し, homogenate 上清に対する抗体 (以下homogenate抗体と略す) にも一部膜抗体が含まれることを明らかにした。 また，膜抗体の肝細胞障害性を更るたるに，肝細 胞浮遊液（緗胞数 $5 \times 10^{4} / \mathrm{ml}$ ) $1.0 \mathrm{ml}$ 亿抗血清 0.5 $\mathrm{ml}$, Hanks液在 $1.0 \mathrm{ml}$ 肪, $37^{\circ} \mathrm{C}, 60$ 分incubate し, 対照として正湍欰清, 非慟化した補体 $\left(56^{\circ} \mathrm{C}\right.$, 30分）走加六たものにつき，1,000rpm，10分遠 沈後の上清についてイソクエン酸脱水素酵素（I $\mathrm{CDH})$ ，グルタミン酸脱水素醅素 (GDH) の 活性を比較検討すると，膜抗体を含を抗血清の 場合はI C D Hの肝細胞よりの遊出が対照にく らべて $2 \sim 3$ 倍高く, mitochondriaに主として 含まれるGDHの遊出は有意の差がみられない。 

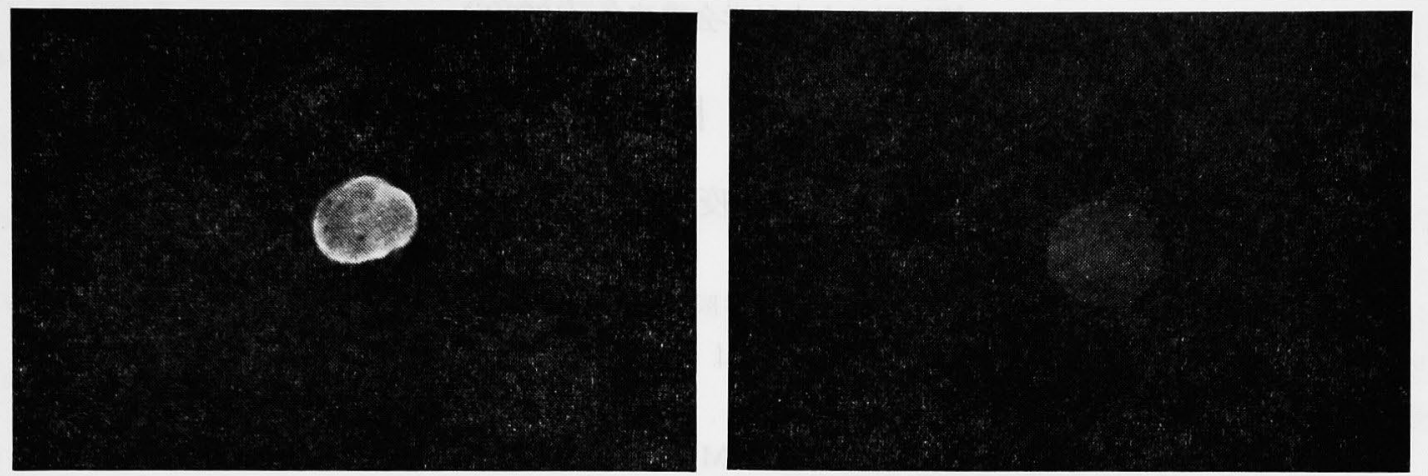

Fig. 1. Photomicrograph of immunofluorescence experiment. (Original magnification $\times 400$ ). Left: Liver cell suspension has been exposed to anti-membrane serum followed by fluorescin conjugated anti-rabbit $\gamma$-globulin goat serum. The periphery of the cell display intense fluorescence characteristic of cell membrane localization of the antigen.

Right: Control experiment performed on the same cell suspension exposed to normal rabbit serum. The cell failed to show ring like staining.

このさい $0.5 \%$ trypan blueによる可染細胞の増 加はreleased enzyme activityの増加と平行する が，ワールブルグ検圧法による肝細胞の酸素消 費量の測定には有意の差がみられず, mitochondriaには直接の作用がないと考えられた．同様 の条件でmitochondria抗体を肝細胞作用させた 場合には, 肝細胞膜への抗体の結合抗よび肝細胞 よりの酵素の遊出はみられない.さらに, immune adherence法を応用して膜抗体を検出した。臨床 例については肝生検でえた肝組織より肝細胞を分 離し, 遊離肝細胞 glucose gelatin veronal buffer (gl-GVB) 浮遊液(細胞数 $10^{5} / \mathrm{ml}$ ) $0.2 \mathrm{ml}$ に患者血 清 $\left(56^{\circ} \mathrm{C} ， 30\right.$ 分非働化) $0.2 \mathrm{ml}$ 加克, $37^{\circ} \mathrm{C}, 30$ 分 ついで $0{ }^{\circ} \mathrm{C}, 30$ 分incubate し, 冷 gl-GVB で 2 回 洗浄後, O型七ト正常血清（20倍希釈） $0.2 \mathrm{ml}$ 浮遊し, $37^{\circ} \mathrm{C}, 5$ 分incubate し, ヒト O 型Rh+ 赤血球 $\left(2 \times 10^{8} / \mathrm{ml}\right) 0.1 \mathrm{ml}$ 加之, $37^{\circ} \mathrm{C}, 10^{\text {分 }}$ incubate後鏡娭する. 阶細胞の膜面に赤血球が粘 着し，口ゼットを形成するものを陽性とする. た，この方法に準じて，前述の各抗血清のラット 肝細胞膜への親和性を検討し，この方法でも膜抗 体以外にhomogenate抗体中にも膜抗体が含まれ ることを示した. さらに, Neville, D.M. の方法
(Biochim. Biophys. Acta, 154:540, 1968) に より肝細胞浮遊液 $0.1 \mathrm{ml}$ に抗血清（膜抗体） 0.1 $\mathrm{ml}$ 加兄, $4{ }^{\circ} \mathrm{C}, 30$ 分後, $22 \%$ sucrose-1 $\mathrm{mM}$ $\mathrm{MgCl}_{2}$ で 2 回洗浄後, fluorescin conjugated antirabbit $\gamma$-globulin goat serumと30分, 室温でincubate し, 前と同様に洗浄後, 蛍光顕微鏡で観察し た. 膜抗体では明らかに肝細胞の周辺にリング状 の強い蛍光がみられ, homogenate抗体でも同様 の所見が壳られるすがあつた（写真 1 ).

臨床例につきimmune adherence法で膜抗体の 出現率を検討した，経時的観察では，急性肝炎 $41.1 \%$ で，同時にhomogenate抗体やmitochondria 抗体の出現率も高いが，急性肝炎(遷延型) 7.6 $\%$ ，慢性肝炎(非活動型) $3.6 \%$ にらべて慢性 肝炎 (活動型) $18.4 \%$ と高いことが注目され, homogenate抗体やmitochondria抗体とはかならず 乙も平行して出現しない. 以上から, 抗肝抗体の うちでも膜抗体が免疫学的肝細胞障害因子の一つ として重視され，再検討される必要があることを 指摘した.

\section{文献}

1) 長島秀夫：肝歲汇関する問題への新しいアプロ -チ6)免疫の面から，日消会誌，66，1171，1969. 